\title{
Development of a Risk Model for Abdominal Wound Dehiscence
}

\section{Mujahid Ahmad Mir*, Farzana Manzoor, Balvinder Singh, Imtiyaz Ahmad Sofi, Abu Zaved Rameez, Sheikh Imran Farooq}

Department of General Surgery, Government Medical College, Srinagar, India

Email: ^drmamir1024@gmail.com

How to cite this paper: Mir, M.A., Manzoor, F., Singh, B., Sofi, I.A., Rameez, A.Z. and Farooq, S.I. (2016) Development of a Risk Model for Abdominal Wound Dehiscence. Surgical Science, 7, 466-474. http://dx.doi.org/10.4236/ss.2016.710063

Received: September 9, 2016

Accepted: October 16, 2016

Published: October 19, 2016

Copyright $\odot 2016$ by authors and Scientific Research Publishing Inc. This work is licensed under the Creative Commons Attribution International License (CC BY 4.0).

http://creativecommons.org/licenses/by/4.0/

\section{Abstract}

Objectives: To identify independent risk factors for abdominal wound dehiscence and develop a risk model to recognize high risk patients. Methods: The samples studied were patients who underwent midline laparotomy in the department of surgery, SMHS Hospital Srinagar from March 2009 to April 2015. For each case of abdominal wound dehiscence, three controls were selected from a group of patients who had undergone open abdominal surgery as close as possible in time. Preoperative, perioperative, and postoperative variables and in-hospital mortality were studied for all patients. Cases were compared with controls using the chi-square test or the MannWhitney U-test for categorical or continuous data, respectively. Subsequently, multivariate stepwise logistic regression with backwards elimination test used to identify main independent risk factors of abdominal wound dehiscence. The resulting regression coefficients for the major risk factors were used as weights for these variables to calculate a risk score for abdominal wound dehiscence. Results: 140 cases of abdominal wound dehiscence were reported and compared with 420 selected controls. All variables that were significant in univariate analyses were entered in a multivariate stepwise logistic regression to determine which variables were significant independent risk factors. Major independent risk factors were male gender, chronic pulmonary disease, corticosteroid use, smoking, obesity, anemia, jaundice, ascites, and sepsis, type of surgery, postoperative coughing, and wound infection. Based on these findings, a risk model was developed. Conclusions: The model can give an estimate of the risk of abdominal wound dehiscence for individual patients. High-risk patients may be planned preventive wound closing with reinforcements as mesh.

\section{Keywords}

Abdominal Wound Dehiscence, Risk Factors, Risk Model, Abdominal Complications 


\section{Introduction}

Abdominal wound dehiscence is among the most dreaded complications faced by surgeons and is of greatest concern because of the risk of evisceration, the need for immediate intervention, and the possibility of repeat dehiscence, wound infection, and incisional hernia formation. It refers to postoperative separation of the abdominal musculoaponeurotic layers. It also entails increased patient treatment cost due to reoperations, postoperative complications and prolonged hospital stay [1]-[8]. The mortality rate following wound dehiscence has ranged from $9 \%-43 \%$, with a recent review reporting a mortality rate of $16 \%$ [9].

Historically, dehiscence rates of up to $10 \%$ have been reported. The incidence, as described in the literature, ranges from $0.4 \%$ to $3.5 \%$ [10]-[23]. In about $20 \%-45 \%$ of cases, evisceration becomes a significant risk factor, which is associated with death during the peri-operative period [24] [25]. Dehiscence may occur anytime after surgery from 1 to more than 20 days. The mean time to wound dehiscence is $8-10$ postoperative days [26] [27].

A multitude of factors may contribute to wound dehiscence. It is often related to technical errors in placing sutures too close to the edge, too far apart, or under too much tension. Several important risk factors for wound dehiscence have been revealed: age ( $>65$ years), hypo-albuminemia, wound infection, ascites, obesity, steroid use, chronic obstructive pulmonary disease, pneumonia, cerebrovascular accident with residual deficit, anemia (hematocrit $<30$ ), prolonged ileus, post-operative coughing, emergency operation, operative time greater than 2.5 hours, and postgraduate year 4 resident as surgeon [17] [28].

Our study aimed to evaluate non-technical risk factors for abdominal wound dehiscence and to frame a risk model which can be used to assess the risk for individual patients, and help advocate preventive strategies in high-risk patients.

\section{Aims and Objectives}

To evaluate risk factors for abdominal wound dehiscence and to design a risk model based on independent risk factors.

\section{Materials and Methods}

The study entitled "Development of a Risk Model for Abdominal Wound Dehiscence" was conducted in Post-Graduate Department of Surgery Government Medical College, Srinagar from March 2009 to April 2015. We developed an observational, longitudinal, analytical and prospective study where the sample studied were patients who underwent midline laparotomy during the study period. Patients operated for ventral hernias, incisional hernias, or other types of laparotomy were not included, as were those who underwent surgery in other departments of the hospital.

The ratio of cases to controls in our study was 1:3. Controls were not matched for age, sex, or type of surgery. Patients who underwent open abdomen treatment were not included in our surgery. Patient and surgery-related variables before, during and after 
surgery and the mortality during hospital stay were studied for whole study population. Documentation of purulent discharge or wound site infection before the diagnosis of dehiscence, or the wound site exploration done on suspicion of infection with culture growing pathogens within 30 days of operation was considered as wound infection.

Comparison of cases and controls was done using chi-square test and the MannWhitney U-test respectively for categorical and continuous data. Multivariate stepwise logistic regression with backwards elimination test was used to recognize chief unfettered risk factors of abdominal wound dehiscence. The ensuing regression coefficients for the major variables were used as their weights to calculate a risk score for abdominal wound dehiscence. Patient data confidentiality was maintained throughout the study.

\section{Results}

140 (109 male and 31 female) cases of abdominal wound dehiscence were reported and compared with 420 (252 male and 168 female) selected controls. Mean age for both groups was 57.86 years (range 18 - 95). Abdominal wound dehiscence was reported at a mean of $10^{\text {th }}$ postoperative day (range: 5 - 35 days). Hospital stay of cases was significantly prolonged $(P<0.001)$ as compared to control group. Mortality during the hospital stay was $25 \%$ and $9 \%$; respectively for the two groups of study population $(P<$ 0.001). 119/140 required surgical intervention for the treatment of abdominal wound dehiscence and 9/119 patients developed recurrence within 30 days of reoperation (7.56\%). None of them developed second recurrence. There was no statistically significant difference between the conservatively treated patients and those treated operatively in terms of hospital stay [median 32 days versus 36 days $(P=0.439)$ ], age $(P=0.359)$, mortality $(P=0.398)$, and comorbidity (all $P<0.04)$.

Table 1 depicts the results of the univariate analysis. Following variables were significantly more prevalent in cases as compared to those in the control group: old age, male gender, obesity (BMI > 27) hypertension, chronic pulmonary disease, ascites, anemia, jaundice, sepsis, emergency surgery, postoperative coughing, wound infection, smokers ( $>20$ pack years) early stage malignancy and type of surgery (all $P<0.001$ ) corticosteroid use (0.004). The variables ASA score $(P=0.145)$, albumin level, $(P=0.020)$, uremia $(P=0.049)$, diabetes mellitus $(0.745)$, previous laparotomy $(0.883)$, operative time (0.131), disseminated malignancy $(0.141)$ and postoperative vomiting $(0.500)$ were not found to be significant risk factors.

Statistically significant variables of univariate analysis were entered in a multivariate stepwise logistic regression to find out significant independent risk factors as shown in Table 2. Surgery on abdominal wall being clean was chosen as the reference category for the evaluation of type of surgery. Age less than 30 years was taken as reference category for the evaluation of variable "age". In comparison with the significant risk factors, none of the other variables age, hypertension, and malignant disease with no distant metastasis was statistically insignificant.

We developed a risk model for abdominal wound dehiscence. The risk scores, weighing the various factors by using the resulting regression coefficients in the logistic 
Table 1. Characteristics of the two groups in the study.

\begin{tabular}{|c|c|c|c|c|c|}
\hline S. No & Variable & $\begin{array}{c}\text { Abdominal wound } \\
\text { dehiscence group }(\mathrm{n}=140)\end{array}$ & Control group $(n=420)$ & $\begin{array}{l}\text { Pearson } \\
\text { Chi-square }\end{array}$ & $P$-value \\
\hline \multirow{7}{*}{1} & Age (years) & & & 33.969 & $<0.001$ \\
\hline & $<30$ & $1.4 \%(2)$ & $7.4 \%(31)$ & & \\
\hline & $30-39$ & $5.7 \%(8)$ & $17.6 \%(74)$ & & \\
\hline & $40-49$ & $11.4 \%(16)$ & $! 5.0 \%(63)$ & & \\
\hline & $50-59$ & $20.7 \%(29)$ & $20.0 \%(84)$ & & \\
\hline & $60-69$ & $28.6 \%(40)$ & $25.0 \%(105)$ & & \\
\hline & 70 and above & $32.1 \%(45)$ & $15.0 \%(63)$ & & \\
\hline \multirow{3}{*}{2} & Sex & & & 13.910 & $<0.001$ \\
\hline & Male & $77.9 \%(109)$ & $60.5 \%(254)$ & & \\
\hline & Female & $22.1 \%(31)$ & $39.5 \%(166)$ & & \\
\hline \multirow{3}{*}{3} & Body mass index & & & 19.934 & $<0.001$ \\
\hline & $\leq 27$ & $45.7 \%(64)$ & $66.9 \%(281)$ & & \\
\hline & $>27$ & $54.3 \%(76)$ & $33.1 \%(139)$ & & \\
\hline \multirow{5}{*}{4} & ASA Score & & & 3.741 & 0.154 \\
\hline & I & $91.4 \%(128)$ & $85.0 \%(357)$ & & \\
\hline & II & $5.7 \%(8)$ & $10.0 \%(42)$ & & \\
\hline & III & $2.9 \%(4)$ & $5.0 \%(21)$ & & \\
\hline & IV & $0 \%(0)$ & $0 \%(0)$ & & \\
\hline 5 & Ascites & $24.3 \%(34)$ & $5.0 \%(21)$ & 44.094 & $<0.001$ \\
\hline 6 & Jaundice & $60.7 \%(85)$ & $8.3 \%(35)$ & 171.111 & $<0.001$ \\
\hline 7 & Anemia & $62.1 \%(87)$ & $34.8 \%(146)$ & 32.401 & $<0.001$ \\
\hline 8 & Uremia & $31.4 \%(44)$ & $23.1 \%(97)$ & 3.871 & 0.049 \\
\hline \multirow{3}{*}{9} & $\begin{array}{l}\text { Albumin level } \\
\qquad(\mathrm{mg} / \mathrm{dl})\end{array}$ & & & 5.431 & 0.020 \\
\hline & $<3$ & $23.6 \%(33)$ & $15.0 \%(63)$ & & \\
\hline & $\geq 3$ & $76.4 \%(107)$ & $85.0 \%(357)$ & & \\
\hline 10 & Sepsis & $20.0 \%(28)$ & $4.8 \%(20)$ & 31.111 & $<0.001$ \\
\hline 11 & $\begin{array}{c}\text { Previous } \\
\text { laparotomy }\end{array}$ & $44.3 \%(62)$ & $45.0 \%(189)$ & 0.022 & 0.883 \\
\hline \multirow[t]{4}{*}{12} & Emergency surgery & $42.9 \%(60)$ & $23.3 \%(98)$ & 19.761 & $<0.001$ \\
\hline & Type of surgery & & & 21.748 & $<0.001$ \\
\hline & 1) Abdominal wall & $7.9 \%(11)$ & $26.7 \%(112)$ & & \\
\hline & $\begin{array}{l}\text { 2) Liver/Gallbladder } \\
\text { /bile Duct/pancreas }\end{array}$ & $21.4 \%(30)$ & $16.9 \%(71)$ & & \\
\hline \multirow[t]{3}{*}{13} & $\begin{array}{l}\text { 3) Vascular/Kidney/ } \\
\text { Adrenal gland/ Spleen }\end{array}$ & $24.3 \%(34)$ & $18.6 \%(78)$ & & \\
\hline & $\begin{array}{l}\text { 4) Esophagus/ } \\
\text { Gastro-duodenal/ } \\
\text { Small-bowel/ } \\
\text { Large-bowel }\end{array}$ & $46.4 \%(65)$ & $37.9 \%(159)$ & & \\
\hline & Operative time & & & 2.286 & 0.131 \\
\hline \multirow[t]{2}{*}{14} & $<150 \min$ & $32.1 \%(45)$ & $39.3 \%(165)$ & & \\
\hline & $>150 \mathrm{~min}$ & $67.9 \%(95)$ & $60.7 \%(255)$ & & \\
\hline
\end{tabular}


Continued

\begin{tabular}{cccccc}
\hline 15 & $\begin{array}{c}\text { Smoking } \\
(\geq 20 \text { pack years })\end{array}$ & $46.4 \%(65)$ & $15.0 \%(63)$ & 58.819 & $<0.001$ \\
16 & Corticosteroid use & $31.4 \%(44)$ & $19.8 \%(83)$ & 8.150 & 0.004 \\
17 & Diabetes- mellitus & $9.3 \%(13)$ & $10.2 \%(43)$ & 0.106 & 0.745 \\
18 & Hypertension & $39.3 \%(55)$ & $13.3 \%(56)$ & 44.499 & $<0.001$ \\
19 & Coughing (post-op) & $17.9 \%(25)$ & $5.0 \%(21)$ & 23.021 & $<0.001$ \\
20 & Vomiting (post-op) & $2.9 \%(4)$ & $1.9 \%(8)$ & 0.454 & 0.500 \\
& Malignancy & & & & \\
21 & Local disease & $35.0 \%(49)$ & $19.8 \%(83)$ & 13.533 & $<0.001$ \\
& metastasis' & $13.6 \%(19)$ & $19.0 \%(80)$ & 2.164 & 0,141 \\
22 & Wound infection & $53.6 \%(75)$ & $10.0 \%(42)$ & 120.609 & $<0.001$ \\
23 & Chronic obstructive & $30.0 \%(42)$ & $15.0 \%(63)$ & 15.508 & $<0.001$ \\
\hline
\end{tabular}

[Data are presented as percentages, with numbers in parentheses]; [Data are presented as percentages, with numbers in parentheses, or as mean $\pm \mathrm{SD}$ (range)].

Table 2. Results of multivariate logistic regression analysis.

\begin{tabular}{|c|c|c|c|c|c|c|c|c|}
\hline \multirow{2}{*}{$\begin{array}{l}\text { S. } \\
\text { No }\end{array}$} & \multirow[b]{2}{*}{ Variable } & \multirow{2}{*}{$\begin{array}{l}\text { Regression } \\
\text { coefficient }\end{array}$} & \multirow{2}{*}{$\begin{array}{c}\text { Standard } \\
\text { error }\end{array}$} & \multirow{2}{*}{ Wald } & \multirow[b]{2}{*}{$P$-value } & \multirow{2}{*}{$\begin{array}{l}\text { Odds } \\
\text { ratio }\end{array}$} & \multicolumn{2}{|c|}{ 95\% C.I for Odds ratio } \\
\hline & & & & & & & $\begin{array}{c}\text { Lower } \\
\text { limit }\end{array}$ & $\begin{array}{l}\text { Upper } \\
\text { limit }\end{array}$ \\
\hline 1 & Male gender & 1.209 & 0.409 & 8.719 & 0.003 & 3.349 & 1.501 & 7.469 \\
\hline 2 & Chronic pulmonary disease & 1.548 & 0.461 & 11.288 & 0.001 & 4.704 & 1.906 & 11.607 \\
\hline 3 & Corticosteroid use & 1.179 & 0.419 & 7.925 & 0.005 & 3.251 & 1.431 & 7.388 \\
\hline 4 & Smoking & 2.454 & 0.429 & 32.771 & 0.000 & 11.637 & 5.023 & 26.963 \\
\hline 5 & Obesity & 1.721 & 0.408 & 17.754 & 0.000 & 5.590 & 2.510 & 12.448 \\
\hline 6 & Anemia & 1.564 & 0.406 & 14.827 & 0.000 & & 2.155 & 10.586 \\
\hline 7 & Jaundice & 3.197 & 0.444 & 51.953 & 0.000 & 24.452 & 10.252 & 58.321 \\
\hline 8 & Ascitis & 2.411 & 0.563 & 18.338 & 0.000 & 11.142 & 3.696 & 33.584 \\
\hline 9 & Sepsis & 2.422 & 0.625 & 14.999 & 0.000 & 11.273 & 3.308 & 38.410 \\
\hline & $\begin{array}{c}\text { Type of surgery } \\
\text { Liver/Gallbladder/bile } \\
\text { duct/pancreas }\end{array}$ & 3.281 & 0.717 & 20.958 & 0.000 & 26.603 & 6.530 & 108.391 \\
\hline 10 & $\begin{array}{l}\text { Vascular/spleen/ } \\
\text { adrenal/Kidney }\end{array}$ & 3.062 & 0.726 & 17.770 & 0.000 & 21.374 & 5.147 & 88.759 \\
\hline & $\begin{array}{c}\text { Esophagus/ } \\
\text { Gastro-duodenum/ } \\
\text { Small bowel/Large bowel }\end{array}$ & 1.786 & 0.604 & 8.731 & 0.003 & 5.965 & 1.825 & 19.500 \\
\hline 11 & Coughing & 1.387 & 0.573 & 5.858 & 0.016 & 4.004 & 1.302 & 12.313 \\
\hline 12 & Wound infection & 3.251 & 0.480 & 45.886 & 0.000 & 25.818 & 10.079 & 66.139 \\
\hline
\end{tabular}

${ }^{a}$ Reference category age $<30$ years; ${ }^{b}$ Overall $\mathrm{P}$ value; ${ }^{\mathrm{c}}$ Reference category abdominal wall.

regression analysis, are shown in Table 3. No points are given if risk factors are absent. A higher value of the score predicts a higher risk. 
Table 3. Risk score for abdominal wound dehiscence.

\begin{tabular}{|c|c|c|c|}
\hline S. No & & Variable & Risk score \\
\hline 1 & & Male gender & 1.209 \\
\hline 2 & & Chronic pulmonary disease & 1.548 \\
\hline 3 & & Corticosteroid use & 1.179 \\
\hline 4 & & Smoking & 2.454 \\
\hline 5 & & Obesity & 1.721 \\
\hline 6 & & Anemia & 1.564 \\
\hline 7 & & Jaundice & 3.197 \\
\hline 8 & & Ascitis & 2.411 \\
\hline \multirow[t]{2}{*}{9} & & Sepsis & 2.422 \\
\hline & & Liver/Gallbladder/bile duct/pancreas & 3.281 \\
\hline \multirow[t]{2}{*}{10} & Type of surgery & Vascular/spleen/adrenal/ Kidney & 3.062 \\
\hline & & Esophagus/Gastro-duodenum/Small bowel/Large bowel & 1.786 \\
\hline 11 & & Coughing & 1.387 \\
\hline 12 & & Wound infection & 3.251 \\
\hline
\end{tabular}

Minimum score $=0$ maximum score $=25.7$.

\section{Discussion}

Abdominal wound dehiscence is a morbid postoperative complication. The mortality rate following wound dehiscence ranges from 9\% - 43\% [9]. Prevention is therefore an important issue, and a cornerstone of this is meticulous surgical technique. It is of immense importance that patients be fully informed beforehand about the complications that can be expected to occur in relation to any surgical procedure. The designed model is intended to predict the risk of wound dehiscence and plan preventive wound closing with mesh.

In our study wound infection was the most important risk factor which is also depicted by most of the studies on this topic [16]-[19]. Bacterial colonization causes intrusion and activation of polymorph nuclear leucocytes and increase in the levels of degradative matrix metallo proteinase's (MMPs). This results in wound degradation in the absence of sufficient tissue inhibitors of MMPs. Moreover, in the wounds of patients with abdominal wound dehiscence, it has been observed that the rate of degradation of collagen exceeds that of its synthesis which adversely affects breaking strength. Low breaking strength can lead to abdominal wound dehiscence especially in presence of increased intra-abdominal pressure and abnormal inflammatory response. Perioperative stress, need for blood transfusion and decreased tissue oxygenation due to anemia affect the immune system and subsequently the process of wound healing. Sepsis leads to hypoperfusion and the patients usually have associated wound infection due to hematogenous seeding. It has been regarded as a risk factor for wound dehiscence by many studies [29]-[31]. Smoking causes vasoconstriction thereby hampering tissue 
oxygenation and hence wound healing.

Men are found to have more risk of wound dehiscence as compared to women in our study. The possible reason may be the confounding variable smoking as most smokers tend to be males. In addition men build up higher abdominal wall tension than women. Increased intra-abdominal pressure results in higher strain on wound edges, predisposing sutures to cut through the muscle and fascia. Ascites and coughing also increase intra-abdominal pressure and increase the risk of wound dehiscence. Delayed wound healing and high incidence of wound dehiscence have been observed in jaundiced patients undergoing surgery. Patients with jaundice have decreased activity of propylhydroxylase in their skin which is necessary for incorporation of proline amino-acid into collagen.

Corticosteroids cause immunosuppression and delay wound healing. Steroid use has been observed as risk factor for abdominal wound dehiscence in our study. This is at par with previous studies [21] [29].

Chronic obstructive pulmonary (COPD) disease increases the risk due to systemic tissue hypoxia. COPD is a frequent disease in elderly and consequently incidence of wound dehiscence is more in elderly. Obesity is observed to be a risk factor for abdominal wound dehiscence in our study. Because of poor nutritional habits and reduced mobility overweight individuals have increased risk of wound dehiscence and hernia formation.

The factors "emergency surgery, old age, hypertension and malignancy" were significant in univariate analysis but not in multivariate analysis in this study. Patients who undergo emergency surgery are generally in worse condition and nutritional state, and the chance of contamination of the surgical field is higher than in elective surgery. Moreover, the performance of the surgeon might be affected at night, which could lead to suboptimal closure of the abdomen at the end of the operation. Patients who undergo emergency surgery are generally in worse condition and nutritional state, and the chance of contamination of the surgical field is higher than in elective surgery. Moreover, the performance of the surgeon might be affected at night, which could lead to suboptimal closure of the abdomen at the end of the operation. The risk model can be used to identify patients at risk. Preventive measures, e.g., the use of mesh and special suture techniques and materials, aimed at decreasing tension on the wound edges, can be investigated and used in these patient groups. We therefore hope that the results of this study will lead to better, evidence-based treatment options for abdominal wound dehiscence and, eventually, a lower incidence of this severe complication.

Limited number of variables related to patient was studied .Other factors like those related to technique of surgery and suture material used were not investigated in this study. Moreover the risk model was not validated .This would have drastically improved the predictive value of the model in identification of patients at risk. Preventive measures, e.g., the use of mesh and special suture techniques and materials, aimed at decreasing tension on the wound edges, can be investigated and used in these patient groups. 


\section{Conclusion}

We observed male gender, chronic pulmonary disease, corticosteroid use, smoking, obesity, sepsis, ascites, jaundice, anemia, type of surgery, coughing, and wound infection as independent risk factors for abdominal wound dehiscence. The risk model framed can give an estimate of the risk of developing abdominal wound dehiscence for individual patients and minimally invasive alternatives or preventive wound closing with reinforcements may be planned wherever desired necessary.

\section{References}

[1] Van Ramshorst, G.H., Nieuwenhuizen, J., Hop, W.C., Arends, P., Boom, J., Jeekel, J., et al. (2010) Abdominal Wound Dehiscence in Adults: Development and Validation of a Risk Model. World Journal of Surgery, 34, 20-27. http://dx.doi.org/10.1007/s00268-009-0277-y

[2] Rebasa, P., Mora, L., Luna, A., Montmany, S., Vallverdú, H. and Navarro, S. (2009) Continuous Monitoring of Adverse Events: Influence on the Quality of Care and the Incidents of Errorsin General Surgery. World Journal of Surgery, 33, 191-198. http://dx.doi.org/10.1007/s00268-008-9848-6

[3] Rebasa, P., Mora, L., Vallverdú, H., Luna, A., Montmany, S., Romaguera, A., et al. (2011) Adverse Events in General Surgery. A Prospective Analysis of 13,950 Consecutive Patients. Cirugía Española, 89, 599-605. http://dx.doi.org/10.1016/j.ciresp.2011.06.007

[4] Carlson, M. (1997) Acute Wound Failure. Surgical Clinics of North America, 77, 607-636. http://dx.doi.org/10.1016/S0039-6109(05)70571-5

[5] Eke, N. and Jebbin, N. (2006) Abdominal Wound Dehiscence: A Review. International Surgery, 91, 276-287.

[6] Rodríguez, J., Codina, A., Ruiz, B., Roig, J., Gironès, J., Pujadas, M., et al. (2005) Factores de riesgo de dehiscenciaaguda de la paredabdominal traslaparotomí́aenadultos. Cirugía Española, 77, 280-286.

[7] Bellón, J. (2005) El cierre de laparotomíaen la líneaalba. Cirugía Española, 77, 114-123. http://dx.doi.org/10.1016/S0009-739X(05)70821-6

[8] Broughton, G., Janis, J. and Attinger, C. (2006) Wound Healing: An Overview. Plastic and Reconstructive Surgery, 117, 1e-S-32e-S.

[9] Pavlidis, T.E., Galatianos, I.N., Papaziogas, B.T., et al. (2001) Complete Dehiscence of the Abdominal Wound and Incriminating Factors. European Journal of Surgery, 167, 351. http://dx.doi.org/10.1080/110241501750215221

[10] Webster, C., Neumayer, L., Smout, R., et al. (2003) National Veterans Affairs Surgical Quality Improvement Program. Prognostic Models of Abdominal Wound Dehiscence after Laparotomy. Journal of Surgical Research, 109, 130-137. http://dx.doi.org/10.1016/S0022-4804(02)00097-5

[11] Wahl, W., Menke, H., Schnütgen, M., et al. (1992) Die Fasciendehiscenz-Ursache und Prognose. Chirurg, 63, 666-671.

[12] Gislason, H., Grønbech, J.E. and Søreide, O. (1995) Burst Abdomen and Incisional Hernia after Major Gastrointestinal Operations-Comparison of Three Closure Techniques. European Journal of Surgery, 161, 349-354.

[13] Armstrong, C.P., Dixon, J.M., Duffy, S.W., et al. (1984) Wound Healing in Obstructive Jaundice. British Journal of Surgery, 71, 267-270. http://dx.doi.org/10.1002/bjs.1800710405

[14] Penninckx, F.M., Poelmans, S.V., Kerremans, R.P., et al. (1979) Abdominal Wound Dehis- 
cence in Gastroenterological Surgery. Annals of Surgery, 189, 345-352.

http://dx.doi.org/10.1097/00000658-197903000-00016

[15] Pavlidis, T.E., Galatianos, I.N., Papaziogas, B.T., et al. (2001) Complete Dehiscence of the Abdominal Wound and Incriminating Factors. European Journal of Surgery, 167, 351-354. http://dx.doi.org/10.1080/110241501750215221

[16] Humar, A., Ramcharan, T., Denny, R., et al. (2001) Are Wound Complications after a Kidney Transplant More Common with Modern Immunosuppression? Transplantation, 72, 1920-1923. http://dx.doi.org/10.1097/00007890-200112270-00009

[17] Makela, J.T., Kiviniemi, H., Juvonen, T. and Laitinen, S. (1995) Factors Influencing Wound Dehiscence after Midline Laparotomy. American Journal of Surgery, 170, 387-390. http://dx.doi.org/10.1016/S0002-9610(99)80309-2

[18] Keill, R.H., Keitzer, W.F., Nichols, W.K., et al. (1973) Abdominal Wound Dehiscence. Archives of Surgery, 106, 573-577. http://dx.doi.org/10.1001/archsurg.1973.01350160185032

[19] Niggebrugge, A.H., Hansen, B.E., Trimbos, J.B., et al. (1995) Mechanical Factors Influencing the Incidence of Burst Abdomen. European Journal of Surgery, 161, 655-661.

[20] Col, C., Soran, A. and Col, M. (1998) Can Postoperative Abdominal Wound Dehiscence Be Predicted? Tokai Journal of Experimental and Clinical Medicine, 23, 123-127.

[21] Riou, J.P., Cohen, J.R. and Johnson Jr., H. (1992) Factors Influencing Wound Dehiscence. American Journal of Surgery, 163, 324-330. http://dx.doi.org/10.1016/0002-9610(92)90014-I

[22] Swaroop, M., Williams, M., Greene, W.R., et al. (2005) Multiple Laparotomies Are a Predictor of Fascial Dehiscence in the Setting of Severe Trauma. American Surgeon, 71, 402-405.

[23] Halasz, N.A. (1968) Dehiscence of Laparotomy Wounds. American Journal of Surgery, 116, 210-214. http://dx.doi.org/10.1016/0002-9610(68)90495-9

[24] Jones, V., Bale, S. and Harding, K. (2004) Acute and Chronic Wounds. Wound Care Essentials: Practice Principles. Lippincott, Williams, \& Wilkins, Philadelphia.

[25] Burger, J.W., Van't Riet, M. and Jeekel, J. (2002) Abdominal Incisions: Techniques and Postoperative Complications. Scandinavian Journal of Surgery, 91, 315-321.

[26] Van't Riet, M., Steyerberg, E.W., Nellensteyn, J., Bonjer, H.J. and Jeekel, J. (2002) MetaAnalysis of Techniques for Closure of Midline Abdominal Incisions. British Journal of Surgery, 89, 1350-1356. http://dx.doi.org/10.1046/j.1365-2168.2002.02258.x

[27] Gislason, H. and Viste, A. (1999) Closure of Burst Abdomen after Major Gastrointestinal Operations-Comparison of Different Surgical Techniques and Later Development of Incisional Hernia. European Journal of Surgery, 165, 958-961. http://dx.doi.org/10.1080/110241599750008071

[28] Webster, C., Neumayer, L., Smout, R., et al. (2003) Prognostic Models of Abdominal Wound Dehiscence after Laparotomy. Journal of Surgical Research, 109, 130-137. http://dx.doi.org/10.1016/S0022-4804(02)00097-5

[29] Carson, J.L., Duff, A., Poses, R.M., et al. (1996) Effect of Anaemia and Cardiovascular Disease on Surgical Mortality and Morbidity. Lancet, 348, 1055-1060. http://dx.doi.org/10.1016/S0140-6736(96)04330-9

[30] Carson, J.L., Noveck, H., Berlin, J.A. and Gould, S.A. (2002) Mortality and Morbidity in Patients with Very Low Postoperative Hb Levels Who Decline Blood Transfusion. Transfusion, 42, 812-818. http://dx.doi.org/10.1046/j.1537-2995.2002.00123.x

[31] Menke, N.B., Ward, K.R., Witten, T.M., et al. (2007) Impaired Wound Healing. Clinics in Dermatology, 25, 19-25. http://dx.doi.org/10.1016/j.clindermatol.2006.12.005 
Submit or recommend next manuscript to SCIRP and we will provide best service for you:

Accepting pre-submission inquiries through Email, Facebook, LinkedIn, Twitter, etc. A wide selection of journals (inclusive of 9 subjects, more than 200 journals)

Providing 24-hour high-quality service

User-friendly online submission system

Fair and swift peer-review system

Efficient typesetting and proofreading procedure

Display of the result of downloads and visits, as well as the number of cited articles

Maximum dissemination of your research work

Submit your manuscript at: http://papersubmission.scirp.org/

Orcontact ss@scirp.org 